\title{
"Impact of the ownership form on cost management: A public-private partnership perspective"
}

\begin{tabular}{|c|c|}
\hline \multirow{5}{*}{ AUTHORS } & Halit Shabani (D) https://orcid.org/0000-0002-0448-0991 \\
\hline & Vlora Berisha (D https://orcid.org/0000-0002-1049-1742 \\
\hline & R http://www.researcherid.com/rid/O-8708-2017 \\
\hline & Vjosa Hajdari (D https://orcid.org/0000-0002-4839-2707 \\
\hline & R http://www.researcherid.com/rid/X-5964-2018 \\
\hline ARTICLE INFO & $\begin{array}{l}\text { Halit Shabani, Vlora Berisha and Vjosa Hajdari (2021). Impact of the ownership } \\
\text { form on cost management: A public-private partnership perspective. Problems } \\
\text { and Perspectives in Management, 19(1), 305-316. } \\
\text { doi:10.21511/ppm.19(1).2021.26 }\end{array}$ \\
\hline DOI & http://dx.doi.org/10.21511/ppm.19(1).2021.26 \\
\hline RELEASED ON & Thursday, 18 March 2021 \\
\hline RECEIVED ON & Monday, 21 December 2020 \\
\hline \multirow[t]{2}{*}{ ACCEPTED ON } & Monday, 08 March 2021 \\
\hline & $(c) E Y$ \\
\hline LICENSE & $\begin{array}{l}\text { This work is licensed under a Creative Commons Attribution } 4.0 \text { International } \\
\text { License }\end{array}$ \\
\hline JOURNAL & "Problems and Perspectives in Management" \\
\hline ISSN PRINT & $1727-7051$ \\
\hline ISSN ONLINE & $1810-5467$ \\
\hline PUBLISHER & LLC "Consulting Publishing Company "Business Perspectives" \\
\hline FOUNDER & LLC "Consulting Publishing Company "Business Perspectives" \\
\hline
\end{tabular}

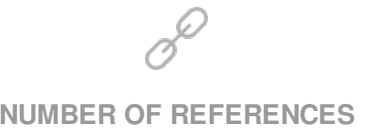

34

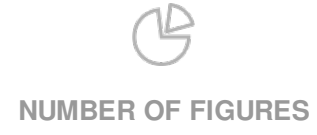

5

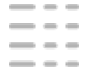

NUMBER OF TABLES

5

C The author(s) 2021. This publication is an open access article. 


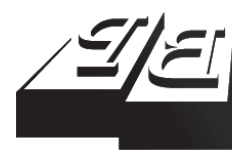

BUSINESS PERSPECTIVES

(O)

LLC "CPC "Business Perspectives" Hryhorii Skovoroda lane, 10 Sumy, 40022, Ukraine www.businessperspectives.org
Received on: $21^{\text {st }}$ of December, 2020 Accepted on: $8^{\text {th }}$ of March, 2021 Published on: $18^{\text {th }}$ of March, 2021

() Halit Shabani, Vlora Berisha, Vjosa Hajdari, 2021

Halit Shabani, Ph.D., Professor, Business Faculty, Bank and Finance Department, University Haxhi Zeka, Kosovo.

Vlora Berisha, Ph.D., Professor, Business Faculty, Accounting and Finance Department, University Haxhi Zeka, Kosovo. (Corresponding author)

Vjosa Hajdari, Ph.D., Teaching Assistant, Business Faculty, Business Administration Department, University Haxhi Zeka, Kosovo.

\section{IMPACT OF THE OWNERSHIP FORM ON COST MANAGEMENT: A PUBLIC-PRIVATE PARTNERSHIP PERSPECTIVE}

\begin{abstract}
The main motive of this study is to evaluate the adaptation of the form of public-private organization to cost control. The empirical analysis for this research includes time-series data from 2008 to 2019 for the EcoHigjiena company by comparing its costs when it was a publicly owned company with the costs over the time the company entered into the partnership agreement. The findings of the study show that public-private ownership is a critical factor in determining total costs of the company by reducing total costs by $10 \%$. The control variables (such as landfill within the municipality, wages and maintenance costs, number of customers and number of employees) for this study also showed significant and robust relationships in the total costs of the company. Wage expenses are an important indicator in increasing the total costs of the company by increasing them by $1.12 \%$, which means that for every employee in the company, total cost decrease by $0.49 \%$. Disposal costs contribute to a $0.25 \%$ increase in total costs. The number of clients is statistically important when viewed from an economic perspective, its impact on total costs is not high, or, in other words, there is no implication because for each client of the company, total expenses increase by $0.002 \%$.
\end{abstract}

\section{Keywords}

costs, labor cost, partnership, organization, sustainability

\section{JEL Classification J31, M10, Q01}

\section{INTRODUCTION}

Governments around the world are calling for the privatization of public services, especially in recent years. In Europe, the privatization of municipal waste services has become extremely widespread (Germà Bel \& Mur, 2009; Germà Bel \& Warner, 2008; Dijkgraaf \& Gradus, 2007, 2011; Gradus et al., 2014). The main reason for the private transfer of some or all public services is the pursuing for a better performance (Simõnes et al., 2012), as in cost recovery, finances, total cost, economies of scale, efficiency of public accountability and institutional management (Massoud \& El-Fadel, 2002). Based on the findings of several recent studies, the main premise of public service privatization lies in issues related to cost concerns and budget constraints (Bel \& Fageda, 2009). For Kosovo as a developing country, financial sustainability and cost management of the waste service sector are still challenging. According to MMPH, KEPA, and GIZ (2018), advancement in the field of waste management in Kosovo is still unbalanced. Some regions are more advanced and have significantly better technical capacity and collection level than some other regions and municipalities. This is probably because in Kosovo different licensed operators for waste collection and transport operate, such as: public, private and only 
one mixed operator: private-public1. EcoHigjiena is the first and only company in Kosovo established under the Public-Private Partnership Agreement. Its activity is in the south-eastern region of Kosovo: Gjilan, Kamenica and Vitina, and has cooperation agreements with the municipality of Novo Berdo. "Public-Private Partnerships (PPPs) stress the transfer and full or partial control of services currently provided by the public sector to the private sector" (Massoud \& El-Fadel, 2002, p. 621). A PPP approach presents public-private partnership as "any action that relies on the agreement of actors in the public and private sector and that also contributes in some way to the improvement of the local economy and the quality of life" (McQuaid, 2000, p. 3).

Establishing public-private partnerships in the waste services sector aims to better manage costs and increase performance. Although this statement is supported by many scholars (Lohri et al., 2014; Massoud \& El-Fadel, 2002; Simonnes et al., 2012), there are also authors who have proven empirically (Kaseva \& Mbuligwe, 2005; Oteng-Ababio, 2010) that governments see the role of the private sector in providing public services with skepticism.

The purpose of this study, therefore, is to examine the effects of public-private collaboration on cost management. The effects of PPP are examined by comparing the costs of a company when it operated as a public operator (before the year 2012) and after 2012 when the company entered into public-private partnership agreements. In this regard, this research contributes to considering the possibility of involving the private sector in waste management as an important sector.

The paper is organized as follows. The first part presents a summary of the study; the second part presents the literature review. The third part describes the Kosovo market for waste collection and experiences of PPP of the "Ecohigjiena Company". The fourth part provides an econometrical model and results of the analysis. The last part contains the conclusion of this study.

\section{LITERATURE REVIEW}

Stakeholders' involvement is important to reach consistency in the management of municipal solid waste (MMSW). However, there is still discussion on the importance of the private sector in providing solutions to improve MMSW. The debate over the privatization of the waste collection sector is shifting from an ideological debate to a more appropriate discussion of political and economic factors Germà Bel and Warner (2008), Dijkgraaf and Gradus (2007), Gradus et al. (2016), Gradus et al. (2014), and Henry et al. (2006) noted that concerns about "cost reduction" need to be balanced with concerns about stakeholder management and the voice of citizens. Bel and Warner (2008), based on empirical studies conducted in North America and Europe, prove that governments should be "pragmatic managers" tasked with managing costs, markets, and political interests simultaneously. However, the empirical results, especially the recent ones in the role of privatization and in particular in terms of "cost advantage", are very mixed.

According to Henry et al. (2006), Kenya as a developing country through the approval of private sector involvement (privatization of some of the public services) has increased efficiency in waste management. In some areas of this country, mainly where businesses operate and areas where the rich live, $47 \%$ of them have stated that they are able to pay a higher fee for better waste services. For the same country, but the research was conducted in 1997 by Esho (1997), similar results in percentage terms were found, $50 \%$ of the inhabitants in the following areas have stated that they are able to pay higher fee to operators because they look forward to having a cleaner environment.

These assertions by citizens alleviate some of the disadvantages of the private sector involvement that "Private waste management treatment can be an expensive venture that can only be supported

1 In Kosovo, there is only one operator with public-private partnership. 
by high monthly payments" (Henry et al., 2006, p. 92). However, perhaps this disadvantage of the more expensive tariff lies with private operators when they involve their operation in areas where residents' incomes are lower (Henry et al., 2006).

There is still serious debate that "cost reduction is the main benefit of privatization". Bel and Warner (2008) have given a critical look at the empirical studies conducted from 1965 to 2007, and show that different authors have different findings regarding "cost reduction with privatization". Their research points out that only a few studies in the 1970s-1980s show that cost reduction correlates with privatization. Whereas there are many other studies analyzed by Bel and Warner (2008), and their empirical findings have not revealed any difference between private and public sector costs. The authors have even encountered studies that their findings have shown that private provisions are more expensive. This finding is in line with those of Esho (1997), and Henry et al. (2006).

Bel and Warner (2008) support the idea that public-private mixing, inter-municipal cooperation, and dynamic contracting (inside and out) can achieve better results for the waste collection sector.

In their study, Dijkgraaf and Gradus (2011), from panel data for the years 1998-2010 of 5,886 operators, found that the cost advantages from privatization are reduced in the long run. Dijkgraaf and Gradus (2011) pointed out that the cost advantage of PPP cooperation is greater compared to privatization. Guerrero et al. (2013) highlighted that stakeholder involvement is essential for efficient waste management. Bel and Mur (2009) found that "inter-municipal cooperation" reduces costs in municipalities with smaller populations. In terms of inter-municipal interaction, Bel and Warner (2016) found that strong factors pushing inter-municipal cooperation are fiscal constraints, spatial and organizational factors. However, Allers and de Greef (2018) study the case of the Netherlands, which is known as a concrete case of inter-municipal cooperation. Analyzing the panel data for 2005-2013 they found no evidence that inter-municipal cooperation smoothes the average total costs of municipality. In fact, the study found that inter-municipal cooperation increases expenses in small and large municipalities, holding unaffected the expenses in medium-sized municipalities. Whereas Massoud and El-Fadel (2002) highlighted the fact that in Lebanon the PPP form of ownership has emerged as a promising alternative to improve the performance of the waste management. In this country, the form of private ownership goes beyond the form of public ownership. In Tanzania, with the privatization of services in the waste sector, solid waste collection has improved from $10 \%$ in 1994 to $40 \%$ in 2001. Lohri et al. (2014) in their study conducted in Ethiopia found that an increase in costs of public-private operators is related to waste transportation and that delays in mitigating the financial deficit jeopardize public-private partnership (PPP), since the provision of good waste management services is achieved only by ensuring financial sustainability.

Waste management sector in Kosovo - Municipal waste in Kosovo is managed by municipalities, as defined in the Law on Waste (Law 04/1-60). They can also be organized in the form of regions, depending on how the provision of services by the respective municipality will be conceived (Helvetas, 2016; MMPH et al., 2018). Municipalities in Kosovo provide infrastructure for municipal solid waste management. Waste management in Kosovo is realized through public and private service providers, while the collected waste is disposed of in regional and municipal sanitary landfills (MMPH et al., 2018). Legislation of the waste sector in Kosovo is in the process of elaboration and harmonization with EU directives (MMPH \& GIZ, 2019; MMPH et al., 2018; Musa, 2018). In Kosovo, the licensed waste management operators are 7 regional waste organizations that provide services in 7 regions in 26 Municipalities.

\subsection{Public-private partnership approach}

There is no general definition of the concept of Public-Private Partnership. However, the European Commission defines this concept as follows:

"PPPs are forms of cooperation between public authorities and the private sector that aim to modernize the provision of infrastructure and strategic public services. In some cases, PPPs include financ- 
ing, designing, building, renovating, managing or maintaining an infrastructure asset; in others, they include the provision of a service traditionally provided by public institutions. While the main focus of PPPs should be on promoting efficiency in public services through risk-sharing and utilizing private sector expertise, they can also alleviate the immediate pressure on public finances by providing an additional source of capital. On the other hand, public sector participation in a project can provide important safeguards for private investors, especially the sustainability of long-term cash flows from public finances, and can include significant social or environmental benefits in a project" (European Union, 2017, p. 6).

The PPP form of organization is a form that public authorities rely on to perform their legal duties (European Union, 2017). PPP maximizes a linear combination of profit, cost management, improving company efficiency and social benefit (Germà Bel \& Fageda, 2009; Bennett \& Iossa, 2006; Cabral \& Saussier, 2012; Poole \& Fixler, 1987; Spoann et al., 2019).

Public-private partnership is an important approach that can protect the country's economy and create a better public life through better waste management (Spoann et al., 2019).

According to Spoann et al. (2019), PPP is often suggested as a tool to better manage costs, im- prove service quality and generally improve the effectiveness of the entire sector. There are different approaches to studying the different dimensions of PPP and their impact on cost reduction. But according to Cabral and Saussier (2012), a clear dimension that we need to pay attention to is the distribution of property rights. One form of collaboration can be called PPP when it involves (European Union, 2017):

- risk allocation (sharing of risks) between parties;

- contribution of each party involved; and

- maintenance and management of the asset, which is the subject of the enterprise.

\subsection{Public-private partnership experience - "EcoHigjiena Company"}

"EcoHigjiena Company" as a company in the form of Public-Private ownership has started since 2012 and is the first and only company in Kosovo established under the Public-Private Partnership Agreement for a 15 -year period. Its main activity is related to the provision of services for waste collection, transportation and disposal in the SouthEastern Region of Kosovo (ECOHigjiena, 2020). The Austrian company "Ecovision" from "Moerser Group-Austria", based on the decision of the assembly of Gjilan No.16/4339 and based on the Law on PPP, No.03/L-090, has been interested in join-

Table 1. Summarizing data on "EcoHigjiena" and its area of operation

Source: Presentation and calculations of the authors based on the reports of the Kosovo Agency of Statistics (ASK, 2018a; MMPH \& GIZ, 2019; Shina \& Gjinolli, 2017).

\begin{tabular}{|c|c|c|c|c|c|c|c|c|c|c|c|}
\hline 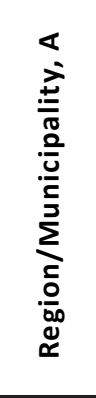 & 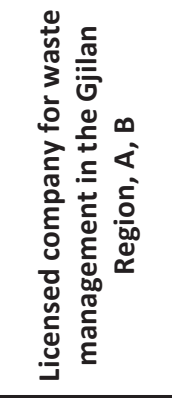 & $\begin{array}{l}u \\
\infty \\
\infty \\
\frac{a}{2} \\
\frac{0}{n} \\
\frac{n}{d} \\
\frac{c}{3} \\
0\end{array}$ & 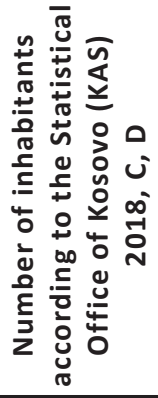 & 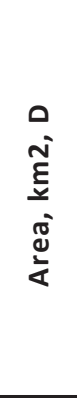 & 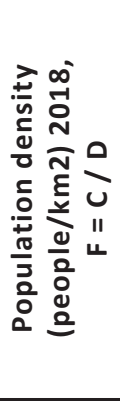 & 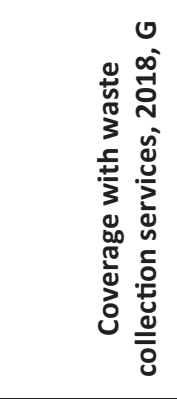 & & 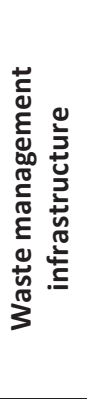 & 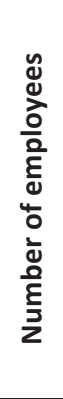 & 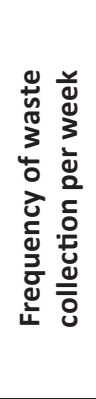 & 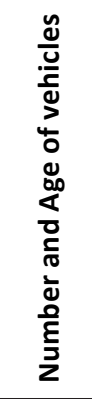 \\
\hline $\begin{array}{l}\text { Gjilan } \\
\text { region }{ }^{2}\end{array}$ & $\begin{array}{c}\text { KRM } \\
\text { "Ekohigjiena" }\end{array}$ & $\begin{array}{l}\text { Mix } \\
\text { PPP }\end{array}$ & 171179 & 1413 & 121 & $\begin{array}{l}\text { Coverage in } \\
\% \text { number of } \\
\text { households } \\
\text { receiving the } \\
\text { service (2018) }\end{array}$ & $61 \%$ & $\begin{array}{l}\text { ST } \\
\text { LR }\end{array}$ & 140 & $\begin{array}{c}\text { 7/7 } \\
\text { Once a } \\
\text { day }\end{array}$ & $22 / 13$ \\
\hline
\end{tabular}

2 Gjilan region includes the following municipalities: Gjilan, Kamenicë, Viti, Novoberdë, Ranillugë, Partesh, and Kllokot. 
ing the funds of its capital in the amount of 51\% of shares in relation to that of the public company of the municipality of Gjilan "KRM Higjiena SHA" of $49 \%$ of shares, to create a joint venture according to the form of PPP ownership, named "Ecohigjiena" (Shabani \& Peci, 2018). The organizational structure of "EkoHigjiena Company", consists of the Board of Directors, chairman and three members from the private partner, two members from the municipality of Gjilan, and 1 member from the municipality of Viti and Kamenica (ECOHigjiena, 2020; Shabani \& Peci, 2018).

In 2019, the size of the market in the service area of "EkoHigjiena Company" included about 171,179 inhabitants (ASK, 2018b; ECOHigjiena, 2020).

According to the work report (2019) of "EcoHigjiena", in this area there were about 34,665 households (on average 5 inhabitants in one household). By the end of 2019, the registered customers in the EcoHigjiena database are a total of 42,052 registered customers, out of which 23,657 are active customers. Active clients include 21,423 household clients; 1,962 business and industry clients; and 272 clients of institutions. The invoicing realized without VAT during 2019 was $1,512,940.69$ Euros, while the collection realized without VAT for this year is $1,435,400$ Euros. To improve the efficiency of waste collection and reduce the cost for 1 collection team (CT), the company hires a maximum of three workers $(C T=1$ truck +1 driver +2 loader); 1 CT empties 25 containers $1.1 \mathrm{~m}^{3}$ per hour, and the team works on 2 honors as needed.

\section{METHODOLOGY}

Empirical analysis is performed to find out the relationship between ownership (public and mixed: private-public) and cost management of "EcoHigjena Company". The analysis is conducted by comparing the costs of the company before the year $2012^{3}$ with the costs after the year 2012, when the company had made PPP partnership agreement. The model is based on the study of Bel and Costas (2006) and Dijkgraaf and Gradus (2011); based on comparable studies, it is common to include oth- er factors that are expected to have incidence on the dependent variable (total costs). For this study, the control variables are: landfill in the municipality; salary expenses; maintenance costs of vehicles (trucks); number of clients and number of employees. Data regarding the organizational structure and other data of the company EcoHigjiena were obtained through interviews conducted with the company's management, as well as from work reports ECOHigjiena (2008-2019). Regarding the costs of the company Ecohigjiena, the data were obtained through a structured questionnaire. Data on the number of inhabitants, area in $\mathrm{m}^{2}$ of the Gjilan region, and population densities were obtained from the Kosovo Agency of Statistics. Data on waste management infrastructure (Municipal landfill) are taken from the report of Kosovo Agency for Environmental Protection (KEPA). Data on frequency of waste collection per week, the number of employees, the number and age of vehicles were obtained through interviews, questionnaires and work reports of ECOHigjiena (2008-2019). Table 1 presents a summary of data of EcoHigjiena and its area of operation.

Empirical model - the model is based on the econometric model developed by Bel and Mur (2009) modifying it for the purposes of this study:

\section{$T C=F$ (ownership, landfill,} wage, maintenance, number of clients, number of workers).

The dependent variable for this study is the Total Cost minus the costs of wages and vehicles maintenance. Since these costs can diverge, it was necessary to see the impact of these costs on the total cost. The average age of waste transport vehicles in Ecohigjien is 13 years, so it is supposed that maintenance for them is more frequent, in this way they can influence the total cost. The total cost can also be influenced by the population in the Gjilan region (as a representative of the amount of waste generated). The cost of the company at the same time and the quality of service can also be affected by the frequency of waste collection and control variables such as population density, landfill, wages and maintenance of vehicles.

3 The company had public ownership. 
Table 2. Explanation of variables

Source: Authors' summary of variables.

\begin{tabular}{|c|c|c|c|}
\hline \multicolumn{2}{|c|}{ Variables } & \multirow[t]{2}{*}{ Explanation of variables } & \multirow[t]{2}{*}{$\begin{array}{l}\text { Expected effects of each } \\
\text { variable }\end{array}$} \\
\hline $\begin{array}{l}\text { Dependent } \\
\text { variable }\end{array}$ & & & \\
\hline \multirow{7}{*}{$\begin{array}{l}\text { Independent } \\
\text { variable }\end{array}$} & \multirow[t]{2}{*}{ Ownership } & $\begin{array}{l}\text { To understand the impact of ownership on Total Cost of } \\
\text { EkoHigjiena, the cost behavior of the company before } \\
\text { the year } 2012 \text { will be analyzed when the company was } \\
\text { public owned, and then it will be compare with the cost } \\
\text { behavior of the company after the year } 2012 \text { when the } \\
\text { company started PPP }\end{array}$ & \multirow[t]{2}{*}{$\begin{array}{l}\text { Based on the recent literature, the } \\
\text { effect of this variable is expected to } \\
\text { be undetermined }\end{array}$} \\
\hline & & $\begin{array}{l}\text { The ownership variable is used as a dummy variable } \\
\text { coded with } 0 \text { when the ownership is public and with } 1 \\
\text { when the ownership is mixed PPP }\end{array}$ & \\
\hline & Number of clients & $\begin{array}{l}\text { To measure the number of customers, the data of active } \\
\text { clients provided by the company were taken }\end{array}$ & $\begin{array}{c}\text { Based on the literature and recent } \\
\text { studies, a positive correlation } \\
\text { between the number of clients and } \\
\text { the total costs of the company is } \\
\text { expected }\end{array}$ \\
\hline & $\begin{array}{l}\text { Number of } \\
\text { employees }\end{array}$ & $\begin{array}{l}\text { To measure the impact of wage costs on the total cost, } \\
\text { the number of employees as a control variable was taken }\end{array}$ & $\begin{array}{l}\text { Positive relationship between } \\
\text { the number of workers and the } \\
\text { total costs of the company is also } \\
\text { expected }\end{array}$ \\
\hline & Landfill & $\begin{array}{l}\text { Since the distance of the landfill can affect especially the } \\
\text { fuel costs, the connection of the transfer station and the } \\
\text { regional landfill in the total cost was analyzed }\end{array}$ & $\begin{array}{l}\text { It is expected that the effect of this } \\
\text { variable to be observed in the total } \\
\text { cost }\end{array}$ \\
\hline & Salary costs & $\begin{array}{l}\text { Since wages are a variable, it is expected to affect the } \\
\text { total cost }\end{array}$ & $\begin{array}{l}\text { Salary costs are expected to have a } \\
\text { positive relationship with the total } \\
\text { cost of the company }\end{array}$ \\
\hline & Maintenance costs & $\begin{array}{c}\text { Vehicles maintenance costs are significant because the } \\
\text { vehicles of transport in this company are on average } 13 \\
\text { years old and the need for maintenance is greater }\end{array}$ & $\begin{array}{l}\text { A positive effect between vehicle } \\
\text { maintenance costs and company } \\
\text { costs is expected as well }\end{array}$ \\
\hline
\end{tabular}

A detailed presentation of the model can be shown by the following equation:

$$
\begin{aligned}
& \text { TC }=\beta_{0}+\beta_{1} \text { ownershipPPP }+ \\
& +\beta_{2} \text { LogLandfil }+\beta_{3} \text { Logwage }+ \\
& +\beta_{4} \text { Logmaintrance }+ \\
& +\beta_{5} \text { No.Clients }+\beta_{6} \text { No.worker }+\varepsilon .
\end{aligned}
$$

\section{RESULTS}

Regression analyses were used to analyze the impact of Public-Private ownership, public ownership and other control variables on the total costs of the company. The T-test was used to confirm the hypotheses raised for this study, since the main premise of this research aims to measure the impact of ownership on the total costs of the company. The variables are analyzed by dividing them into three cases: In the first case, all the variables are measured to see how they affect total costs throughout the whole time series (this case is labeled as the "model 1 total"); then, the second case, which includes only the years when the company was a public company (labeled as "model 2 PP"), and the third case labeled ("model 3 PPP") includes the years when the company is under mixed ownership, which means public-private. The results (see Table 4) show that $\mathrm{R}^{2}$ in all three cases is $99 \%$, which means that the independent variables explain the dependent variable (total costs). The value of $R^{2}$ is a very satisfactory value for this study.

The results of the first model (model 1 total) show that all variables are statistically significant. Wage expenses are an important indicator in increasing the total costs of the company by increasing them by $1.12 \%$, which means that for every employee in the company, the costs decrease by $0.49 \%$. Based on the results that indicate that wages expenditures are an important indicator in increasing the total costs of the company, and after the PPP agreement, the company has changed a strategy 
Table 3. Descriptive data

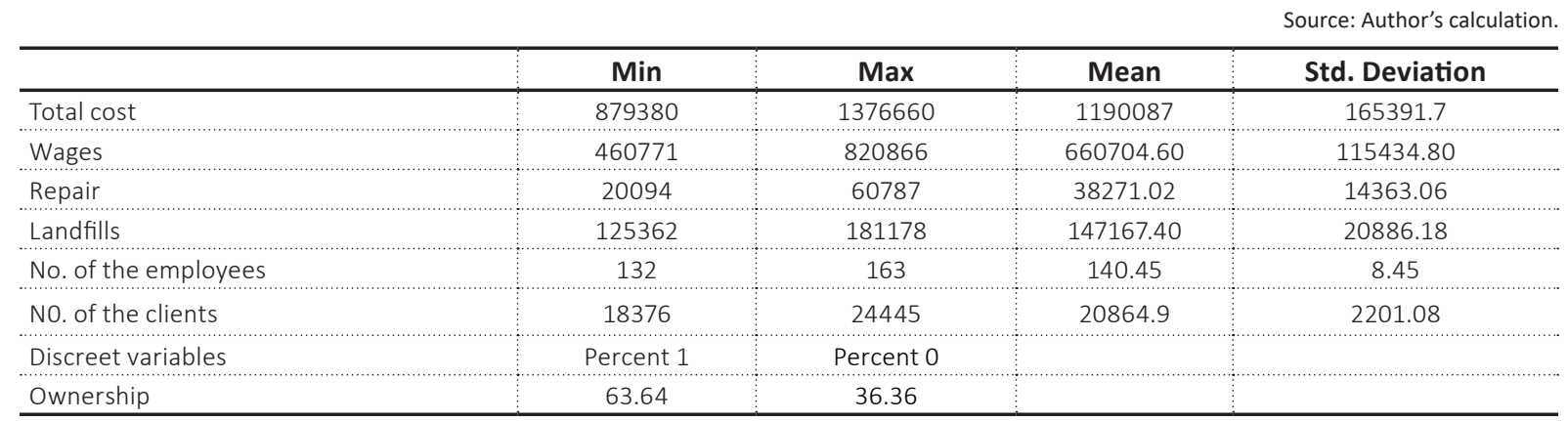

Table 4. Empirical results

\begin{tabular}{|c|c|c|c|}
\hline Independent variable & Model 1 Total & Model 2 PP & Model 3 PPP \\
\hline \multirow{2}{*}{ Wages } & 1.1288 & 1.1028 & 0.2763 \\
\hline & $(10.28)^{* * *}$ & $(6.27)^{* * *}$ & $(0.54)$ \\
\hline \multirow{2}{*}{ Repair } & -0.3758 & -0.2935 & -0.3092 \\
\hline & $(-5.67)^{* * *}$ & $(-2.94)^{* * *}$ & $(-1.51)^{*}$ \\
\hline \multirow{2}{*}{ Landfills } & 0.2488 & 0.1928 & 1.1400 \\
\hline & $(2.18)^{* *}$ & $(1.34)$ & $(1.54)^{*}$ \\
\hline \multirow{2}{*}{ No. of the employees } & -0.0049 & 0.0721 & 0.0547 \\
\hline & $(-3.17)^{* * *}$ & $(5.98) * * *$ & $(2.01)^{* *}$ \\
\hline \multirow{2}{*}{ No. of the clients } & 0.00002 & 0.0002 & 0.0003 \\
\hline & $(3.65)^{* * *}$ & $(2.07)^{* *}$ & $(1.79)^{*}$ \\
\hline \multirow{2}{*}{ Ownership PPP } & -0.1032232 & & \\
\hline & $(3.56)^{* * *}$ & & \\
\hline$R^{2}$ & 0.9986 & 0.9985 & 0.9999 \\
\hline
\end{tabular}

Note: The numbers in brackets and in italics show the t-test values, * means significance level t.90,** significance level t.95, and $* * *$ significance level t.99.

by increasing the number of new employees. This new strategy has affected incretion of efficiency and, at the same time, the receivables of the company have increased. Increasing the number of employees with new employees means lower wages in contrast to the workload of older employees who receive money based on the years of experience gained within the company. EcoHigjiena is a company that collects waste for its clients, and the collected waste must be disposed of in the landfill. Based on the results, these disposal costs increase total costs by $0,25 \%$ for EcoHigjiena. Repair expenses reduce total costs by $0.38 \%$; according to International Accounting Standard No. 16 (IAS 16), repair expenses increase the value of vehicles, so in this case this justifies the result that in the long run repair reduces total costs of the company. The region of Gjilan has a population of 121 inhabitants per $\mathrm{km} 2$, which means that it is dealing with a high dentistry. With such a dentistry, although the number of clients is statistically important, for each client of the company, total expenses increase by $0.002 \%$. Based on the main premise of this paper, which is the impact of ownership on total costs, and by analyzing this variable, it is seen that it is a very important variable, which is statistically significant and, at the same time, shows that PPP ownership of the enterprise affects total costs to reduce them by $10 \%$. Such a result is also consistent with the findings of Germà Bel and Mur (2009), Dijkgraaf and Gradus (2011), Gradus et al. (2014), and Simõnes et al. (2012). To clarify this result of the study, Figure 2 is analyzed. Figure 2 shows that the company's pre-privatization costs have been increasing every year and after privatization have maintained a distribution balance.

The results from Model 2 PP (see Table 4), when the company Ecohigjiena before 2012 was publicly owned, show that all variables turned out to be statistically significant except landfill costs. All results have turned out to be the same as those of the Model 1 labeled total, except in the case of the number of employees where in the public model 


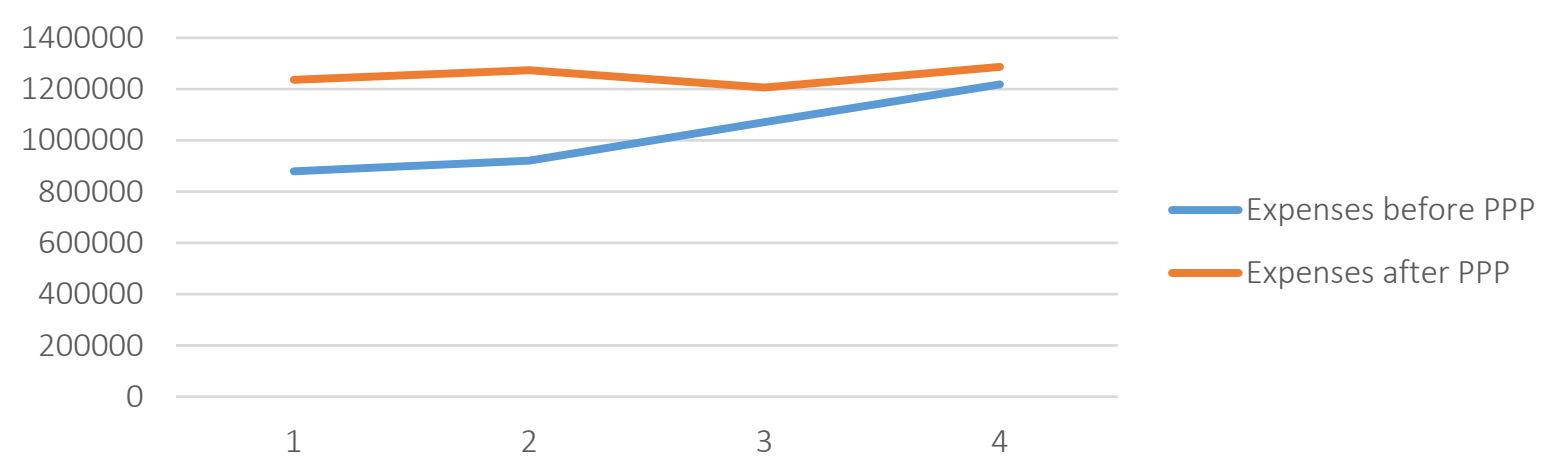

Figure 1. Distribution of total costs before and after privatization

(PP) and the mixed model (PPP) they have turned out to have an impact on total costs by increasing costs by $7 \%$ and $5 \%$, respectively. Depositing expenses in the PP model have turned out to be statistically insignificant because Figure 3 shows that these costs have not had any major fluctuation, these costs remain approximately the same but when the company has shifted ownership to PPP, it can be seen that these costs have a volatility, making the depositing costs increase the total costs by $1.14 \%$. The main difference between these three models is seen in the PPP model, because the wage expenses seem to be not a very important factor in defined total costs of Ecohigjiena Company after the PPP agreement. This result can be explained by the fact that after the PPP Agreement, the company has changed its strategy by hiring new employee with minimal initial wages.

Figure 4 shows that the main difference between the two models about wages expense is that when Ecohigjiena was PP, the wages expenses were lower compared to PPP, but when analyzing the distribution, a linearity is noticed in terms of wage expenses after the PPP agreement.

Table 5. Description of the independent variables and the results obtained

Source: Authors' presentation.

\begin{tabular}{|c|c|c|c|}
\hline \multicolumn{3}{|c|}{ Variables } & \multirow{2}{*}{$\begin{array}{l}\text { Result: Confirmation or non-confirmation of the } \\
\text { hypothesis }\end{array}$} \\
\hline $\begin{array}{l}\text { Dependent } \\
\text { variable }\end{array}$ & \multicolumn{2}{|c|}{ Total costs } & \\
\hline \multirow{6}{*}{$\begin{array}{l}\text { Independent } \\
\text { variable }\end{array}$} & Number of clients & $\begin{array}{l}\text { Number of active clients in } \\
\text { the Gjilan region }\end{array}$ & $\begin{array}{l}\text { From a statistical point of view, it turns out that the number of } \\
\text { clients is statistically significant, but in economic terms, this does } \\
\text { not mean that there is any major impact given to the number of } \\
\text { clients on total costs }\end{array}$ \\
\hline & $\begin{array}{l}\text { Number of } \\
\text { employees }\end{array}$ & $\begin{array}{l}\text { Number of active employees } \\
\text { in the company Ecohigjienta }\end{array}$ & $\begin{array}{c}\text { The number of employees, although it is expected to have a } \\
\text { positive sign on the so called total model } 1 \text {, has turned out to } \\
\text { have a negative sign }\end{array}$ \\
\hline & Wages & $\begin{array}{l}\text { Wage expense is taken } \\
\text { from Questioners with } \\
\text { EcoHigjiena }\end{array}$ & There is a positive relationship between wages and total costs \\
\hline & Repairs & $\begin{array}{l}\text { Repair is also taken } \\
\text { from Questioners with } \\
\text { EcoHigjiena }\end{array}$ & There is significant and has negative sign in total cost \\
\hline & Landfills & $\begin{array}{l}\text { Deposit expense is taken } \\
\text { from Questioners with } \\
\text { EcoHigjiena }\end{array}$ & $\begin{array}{l}\text { Variable landfills meet all expectations both in terms of sign and } \\
\text { sustainability, and its impact on total cost }\end{array}$ \\
\hline & Ownership PPP & $\begin{array}{l}\text { Ownership is a dummy } \\
\text { variable }\end{array}$ & $\begin{array}{l}\text { Ownership has a positive impact on total costs. It has cost } \\
\text { stability with mixed ownership as opposed to when it was public }\end{array}$ \\
\hline
\end{tabular}




$$
\begin{array}{r}
180000 \\
160000 \\
140000 \\
120000 \\
100000 \\
80000 \\
60000 \\
40000 \\
20000
\end{array}
$$

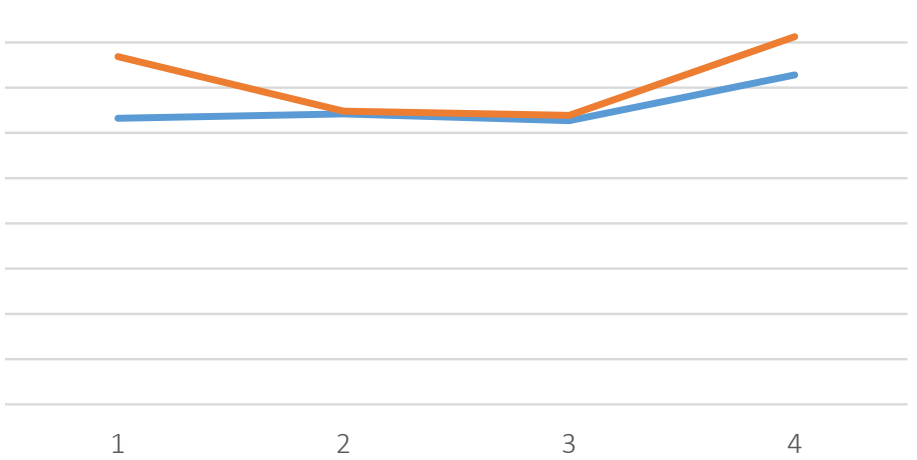

Figure 2. Depositing expenses

900000

800000

700000

600000

500000

400000

300000

200000

100000

0

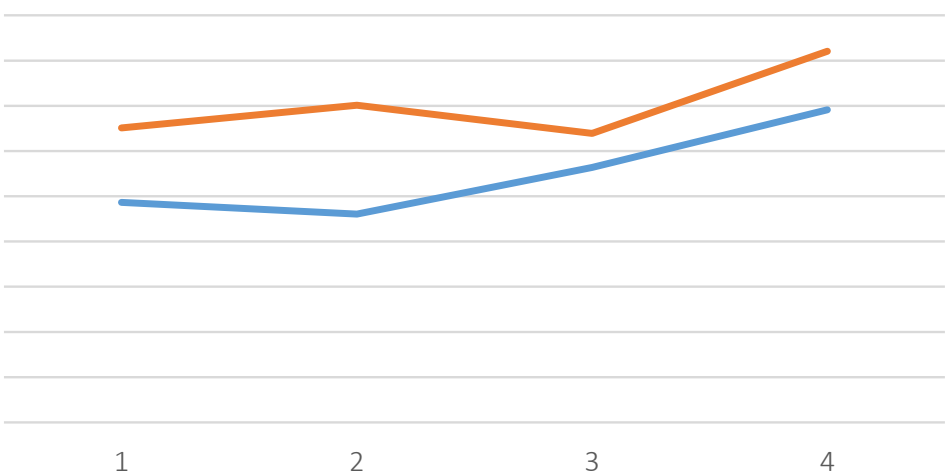

Figure 3. Wages expense

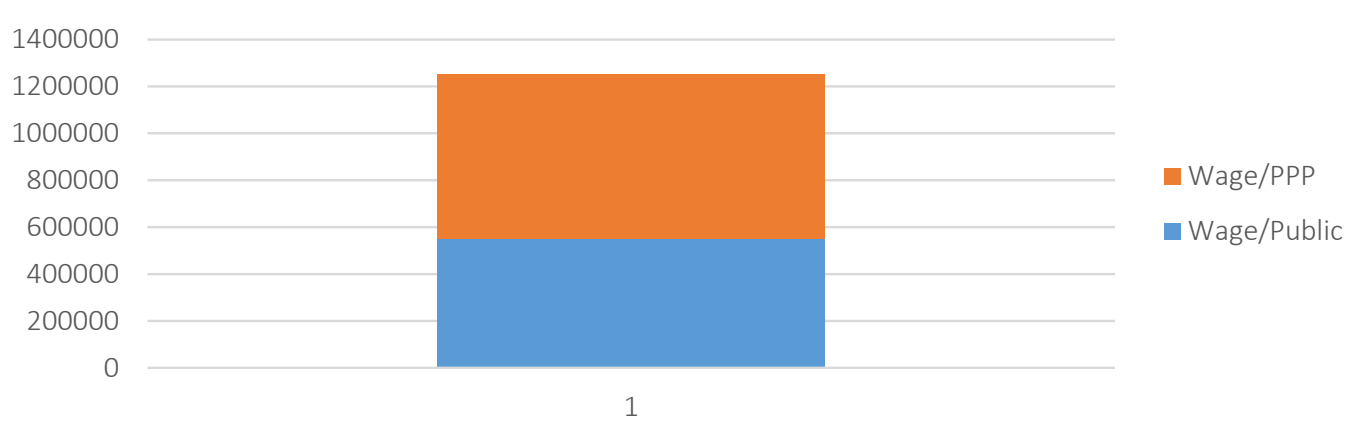

Figure 4. Wages in the period of public and mixed ownership

Source: Authors.

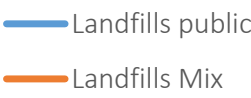

Wage/Public

Wage/Mix

Source: Authors. 


\section{CONCLUSION}

This study examined the impact of public and private ownership on the level of costs. The waste sector is a sector of vital importance to all governments of the world, since it directly affects a cleaner environment and a healthier life for the public. The mixed ownership factor in the study was found to be important for the sustainable mitigation of costs of waste companies. The result show that the ownership factor has a statistically significant effect on total costs. With entering into the PPP cooperation agreement, the company's costs were managed more effectively. Findings of the empirical research show that the costs with mix partnership were reduced in total by $10 \%$. An important finding is also that the company's strategy "to increase the number of employees" has reduced total costs, because it has increased, at the same time, the efficiency and has increased collections of the receivables. An increase in the number of employees with new employees means lower wages than with the workload of older employees who receive money based on the length of service achieved within the company, which leads to a doubling of costs. Based on the results, this study is a good reference for waste companies considering entering into a partnership agreement, as the PPP ownership has a positive effect on sustainability and cost reduction.

\section{AUTHOR CONTRIBUTIONS}

Conceptualization: Vlora Berisha.

Data curation: Vjosa Hajdari.

Formal analysis: Vjosa Hajdari.

Investigation: Vjosa Hajdari.

Methodology: Vlora Berisha.

Project administration: Vlora Berisha.

Resources: Halit Shabani.

Software: Vjosa Hajdari.

Supervision: Halit Shabani.

Validation: Vjosa Hajdari.

Writing - original draft: Vlora Berisha.

Writing - review \& editing: Halit Shabani.

\section{REFERENCE}

1. Allers, M. A., \& de Greef, J. A. (2018). Intermunicipal cooperation, public spending and service levels. Local Government Studies, 44(1), 127-150. https:// doi.org/10.1080/03003930.2017.1 380630

2. ASK (Agency of Statistics of Kosova). (2018a). Mbeturinat komunale te grumbulluara. Retrieved from https:// askdata.rks-gov.net/PXWeb/pxweb/sq/askdata/ askdata_08Environment_Mbeturinat_AnketaeMbeturinaveKomunale/waste $01 \mathrm{mb}$.px/table/tableViewLayout $1 /$ ?rxid=eb2d6dc3c016-44ba-9726-17c9ea2e0067

3. ASK (Agency of Statistics of Kosova (2018b). Vlerësimi i popullsisë. https://doi.org/https:// askdata.rks-gov.net/PXWeb/px$\mathrm{web} / \mathrm{sq} /$ askdata/?rxid=c1c2f237d86d-4c2a-bded-1c7f73747640

4. Bel, G., \& Warner, M. (2008). Challenging issues in local privatization. Environment and Planning C: Government and Policy, 26(1), 104-109. https://doi. org/10.1068\%2Fc2601ed

5. Bel, Germà, \& Costas, A. (2006). Do Public Sector Reforms Get Rusty? Local Privatization in Spain. The Journal of Policy Reform, 9(1), 1-24. https://doi. org/10.1080/13841280500513084

6. Bel, Germà, \& Fageda, X. (2009). Factors explaining local privatization: a meta-regression analysis. Public Choice, 139(1-2),
105-119. https://doi.org/10.1007/

s11127-008-9381-Z

7. Bel, Germà, \& Mur, M. (2009). Intermunicipal cooperation, privatization and waste management costs: Evidence from rural municipalities. Waste Management, 29(10), 2772-2778. https://doi.org/10.1016/j.wasman.2009.06.002

8. Bel, Germà, \& Warner, M. (2008) Does privatization of solid waste and water services reduce costs? A review of empirical studies. Resources, Conservation and Recycling, 52(12), 1337-1348. https://doi.org/10.1016/j.resconrec.2008.07.014

9. Bel, Germà, \& Warner, M. E. (2016). Factors explaining inter- 
municipal cooperation in service delivery: a meta-regression analysis. Journal of Economic Policy Reform, 19(2), 91-115. https://doi.org/10.1080/17487870. 2015.1100084

10. Bennett, J., \& Iossa, E. (2006). Delegation of Contracting in the Private Provision of Public Services. Review of Industrial Organization, 29(1-2), 75-92. https://doi.org/10.1007/s11151006-9110-z

11. Cabral, S., \& Saussier, S. (2012). Organizing Prisons through Public-Private Partnerships: a cross-country investigation. BAR - Brazilian Administration Review, 10(1), 100-120. https:// doi.org/10.1590/S180776922012005000010

12. Dijkgraaf, E., \& Gradus, R. (2007). Collusion in the Dutch waste collection market. Local Government Studies, 33(4), 573-588. https://doi. org/10.1080/03003930701417601

13. Dijkgraaf, E., \& Gradus, R. (2011). Efficiency Effects of Privatising Refuse Collection: Be Careful and Alternatives Present. Tinbergen Institute Discussion Paper, 11(3), 156. Retrieved from https://ideas. repec.org/p/tin/wpaper/20110156. html

14. ECOHigjiena. (2020). Biznes Plani dhe Buxheti 2020-2022. Retrieved from company documents of Plan and Budgeting 2020-2022.

15. Esho, L. (1997). An assessment of the role of the private sector in urban infrastructure service provision: a case o- $f$ solid waste management in the City of Nairobi (Thesis submitted in partial fulfillment for the degree of University of Nairobi) Retrieved from http://erepository.uonbi.ac.ke/bitstream/handle/11295/27023/Esho_An\%20 assessment $\% 20$ of $\% 20$ the $\% 20$ role $\% 20$ of $\% 20$ the $\% 20$ private $\% 20$ sector\%20in\%20urban\%20infrastructure $\% 20$ service $\% 20$ provision. pdf? sequence $=3 \&$ is Allowed $=y$

16. European Union. (2017). Handbook on Public Private Partnership (PPP) in Built Heritage Revitalisation Projects. Retrieved from https://www.interreg-central. eu/Content.Node/O.T1.1-Handbook-new.pdf

17. Gradus, R., Dijkgraaf, E., \& Schoute, M. (2016). Is there still collusion in the Dutch waste collection market? Local Government Studies, 42(5), 689697. https://doi.org/10.1080/0300 3930.2016.1194267

18. Gradus, R., Dijkgraaf, E., \& Wassenaar, M. (2014). Understanding Mixed Forms of Refuse Collection, Privatization, and Its Reverse in the Netherlands. International Public Management Journal, 17(3), 328343. https://doi.org/10.1080/1096 7494.2014.935237

19. Guerrero, L. A., Maas, G., \& Hogland, W. (2013). Solid waste management challenges for cities in developing countries. Waste Management, 33(1), 220-232. https://doi.org/10.1016/j.wasman.2012.09.008

20. Helvetas. (2016). Local waste management plan 2016-2021. Retrieved from http://helvetasks.org/demos2/wp-content/ uploads/2017/10/Plani-lokalper-menaxhimin-e-mbeturinaveGraqanice-ENG.pdf

21. Henry, R. K., Yongsheng, Z., \& Jun, D. (2006). Municipal solid waste management challenges in developing countries Kenyan case study. Waste Management, 26(1), 92-100. https://doi.org/10.1016/j.wasman.2005.03.007

22. Kaseva, M. E., \& Mbuligwe, S. E. (2005). Appraisal of solid waste collection following private sector involvement in Dar es Salaam city, Tanzania. Habitat International, 29(2), 353-366. https://doi.org/10.1016/j.habitatint.2003.12.003

23. Lohri, C. R., Camenzind, E. J., \& Zurbrügg, C. (2014). Financial sustainability in municipal solid waste management - Costs and revenues in Bahir Dar, Ethiopia. Waste Management, 34(2), 542-552. https://doi.org/10.1016/j. wasman.2013.10.014
24. Massoud, M., \& El-Fadel, M. (2002). Public-Private Partnerships for Solid Waste Management Services. Environmental Management, 30(5), 621-630. https://doi. org/10.1007/s00267-002-2715-6

25. McQuaid, R. W. (2000). The Theory of Partnerships - Why have Partnerships. Managing Public-Private Partnerships for Public Services: An International Perspective, 9-35. Retrieved from https://www.semanticscholar.org/paper/The-theory-ofpartnership\%3A-why-have-partnerships-Mcquaid/5414bea3d5ffaa 067916d645e14ffe3801807a40

26. MMPH, \& GIZ. (2019). Menaxhimi i mbeturinave menaxhimi i mbeturinave komunale në kosovë menaxhimi i mbeturinave komunale në kosovë raport mbi gjendjen komunale në kosovë management in kosov. Ministria e Mjedisit dhe Planifikimit Hapeesinor Agjencioni për Mbrojtjen e Mjedisit të Kosovës - GIZ. https://doi.org/10.1017/ CBO9781107415324.004

27. MMPH, KEPA, \& GIZ. (2018). Municipal Waste Management in Kosovo. Retrieved from https:// www.ammkrks.net/repository/ docs/Municipal_Waste_Managment_in_Kosovo_Status_Report_2018.pdf

28. Musa, D. (2018). Waste management in Kosovo: Identifying challenges in the sector. Institute for Development Policy (INDEP), 1-33. Retrieved from https://indep.info/wp-content/uploads/2018/07/WM_ENG. pdf

29. Oteng-Ababio, M. (2010). Private sector involvement in solid waste management in the Greater Accra Metropolitan Area in Ghana. Waste Management \& Research, 28(4), 322-329. https://doi. org/10.1177/0734242X09350247

30. Poole, R. W., \& Fixler, P. E. (1987). Privatization of PublicSector Services in Practice: Experience and Potential. Journal of Policy Analysis and Management, 6(4), 612. https://doi. org/10.2307/3323516 
31. Simõnes, P., Cruz, N. F., \& Marques, R. C. (2012). The performance of private partners in the waste sector. Journal of Cleaner Production, 29-30, 214221. https://doi.org/10.1016/j. jclepro.2012.01.027

32. Spoann, V., Fujiwara, T., Seng, B., Lay, C., \& Yim, M. (2019). Assessment of Public-Private Partnership in Municipal Solid
Waste Management in Phnom

Penh, Cambodia. Sustainability,

11(5), 1228. https://doi.

org/10.3390/su11051228

33. Shabani, H., \& Peci, F. (2018).

Ecohigjiena - Suksesi i

partneritetit Publiko-Privat.

Kolegji Riinvest. Retrieved from

https://www.researchgate.net/ publication/333812373_Nga_ teoria_ne_praktike_studime_ rasti_nga_kompanite_kosovare

34. Shina, A., \& Gjinolli, P. (2017). Waste Management in Kosovo: Challenges and Opportunities. Retrieved from http://helvetasks.org/demos2/wp-content/ uploads/2017/11/Analiza-e-hendekut-ne-sektorin-e-mbeturinave ENG_03.pdf 